\title{
The Wealth Cycle and Macroeconomic Policy
}

\author{
Tony Makin
}

$\Gamma$

HE state of the Australian economy is usually assessed by reference to the flow aggregates measured in the national accounts. Of primary interest are the standard measures of GDP, national income, consumption, investment and saving, the behaviour of which have implications for inflation, employment and the current account deficit. However, another largely neglected approach to assessing the economy's performance involves examining macroeconomic stocks rather than aggregate flows. This approach centres on changes in the value of the nation's assets (net of foreign claims), which is also a measure of national wealth.

There are two reasons for being interested in wealth movements. First, national wealth estimates provide a supplementary measure of macroeconomic welfare. Any individual household's economic welfare depends not only on its annual income but also on the value of its net assets. So it is for the nation as a whole. Whereas it has become standard practice to report and analyse flow national income data, this is not yet the case for national wealth estimates. Second, movements in national wealth, especially those attributable to changed expectations about the future income-generating capacity of the existing capital stock, have implications for the business cycle of macroeconomic boom and bust and how this cycle is managed by the authorities.

Measures of the standard national accounting aggregates ignore the influence of capital gains and losses on the value of residents' asset holdings, in accordance with international macroeconomic accounting practice. However, the convention of eliminating changes in the valuation of the economy's total capital assets deprives analysts of important macroeconomic information. In effect, it means that macroeconomic behaviour is assessed without regard to the central roles played by the economy's capital assets or by the financial markets that are perpetually evaluating and re-evaluating the worth of those assets. Curiously, we have all become quite used to analysing the short-run macroeconomic dynamics of capitalism by explicitly ignoring the role of capital markets and the capital stock itself.

This neglect of the capital stock in the interpretation of capitalist processes is attrubutable to the influence of Keynesian analysis. Keynes (1936) presumed that the market valuation of capital was grossly inefficient, a presumption which stands in radical contrast to the orthodoxy of the modern finance literature (after Fama, 1976). A central tenet of finance theory has been that financial markets tend to reflect all relevant information about economic fundamentals in valuing financial claims to capital, including prospective income streams. (Malkiel, 1989, provides a useful summary of the so-called efficient markets hypothesis.) The Keynesian and efficient markets interpretations of capital market behaviour thus remain poles apart, and there is little prospect of the twain ever meeting. 


\section{Another Measure of the Boom-Bust Cycle}

The level of the economy's wealth, as measured by the market value of its accumulated capital, can increase either as a result of additional saving by Australian residents, which permits further capital accumulation, or through higher market valuation of the existing stock of capital assets. Using estimates of national wealth, it is possible to identify separately how much of Australia's national wealth has grown due to its saving effort and how much has been due to market valuation changes. Such a decomposition is depicted in Figure 1.

\section{Figure 1}

\section{Saving, valuation effects and Australia's national wealth: changes on a year earlier, 1982-92 (current prices)}

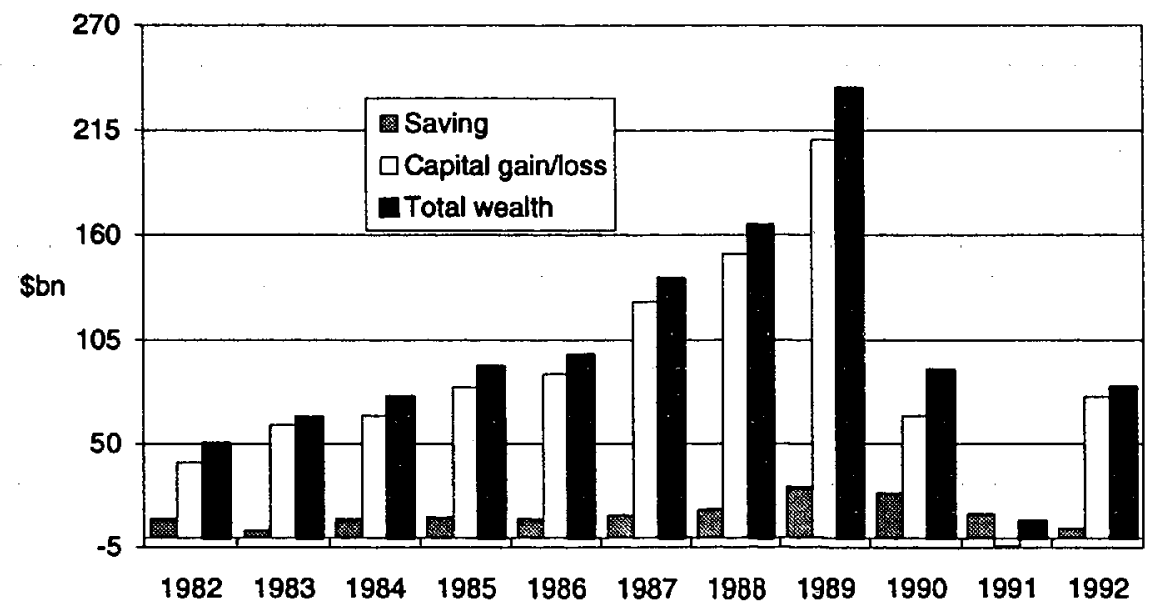

Source: Makin (1994:5).

What is most striking about this decomposition is that annual changes in Australia's wealth tend to be dominated by capital gains and losses rather than changes in national savings. As well, the nation's wealth position can change markedly from year to year and bears a strong relation to the macroeconomic cycle of boom and bust.

The cycle of economic boom and bust has traditionally been measured with reference to changes in real GDP, a flow measure that abstracts from changing financial market perceptions about prospective returns on capital. The year-to-year change in real wealth, however, is a macroeconomic stock-based measure that does explicitly capture market perceptions.

The relationship between the standard business-cycle measure and the real wealth measure is conveyed in Figure 2. Since these estimates were prepared, the ABS (1995) has also, for the first time, published its own 'experimental' national wealth estimates which are broadly compatible with the data in Figure 2, except that the ABS 
data (for 1989-92 only) also include land values on the asset side of the national balance sheet.

Figure 2

\section{Real wealth and real GDP: \% change on a year earlier, $1982-92$}

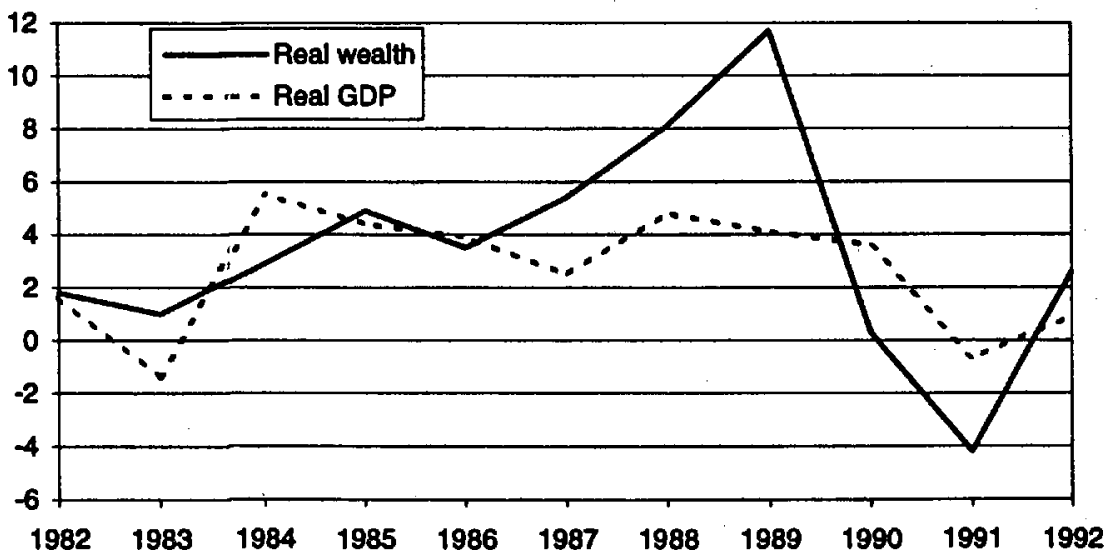

Source: Makin (1994:6).

Note that the annual fluctuations in real national wealth tend to coincide with movements in real GDP from peak to trough, yet are considerably more severe. For instance, the boom of the late 1980s and recession of the early 1990s were far more pronounced according to the real percentage change in national wealth than was actually indicated by the percentage change in real GDP.

\section{Implications for Macroeconomic Policy}

What do wealth fluctuations imply for macroeconomic policy management? Indeed, to what extent are fluctuations in these measures themselves attributable to domestic policy influences?

According to Keynesian macroeconomics, the main justification for macroeconomic policy intervention is to mitigate economy-wide disturbances stemming from changes in business sentiment about private-sector investment. Keynesians simply presume that interventionist fiscal and monetary policies stabilise the business cycle by smoothing out booms and busts. Yet, in practice, macroeconomic policy interventions can themselves generate unfounded market expectations and introduce an additional source of uncertainty about the future. For instance, activist monetary policy that forces short-term interest rates below long-term rates can artificially stimulate asset prices, creating a temporary wealth boom. Alternatively, monetary policy that forces up short-term interest rates can artificially depress asset prices and temporarily generate a recession, as recent experience has shown. 
One striking feature of the earlier charts is that, in the late 1980s, the sharp rise in Australia's wealth was overwhelmingly determined by valuation effects. Even between June 1987 and June 1988, there was still a strong overall rise in national wealth despite the much vaunted October 1987 stockmarket collapse that prompted monetary expansion in Australia and abroad. This monetary expansion, working with the usual lag of up to 18 months, fuelled the subsequent boom of the late $1980 \mathrm{~s}$. In response to this boom, the stance of monetary policy was sharply reversed, as indicated by shortterm interest rates peaking at 18 per cent in mid 1989. This severe monetary contraction contributed to the collapse of national wealth between 1990 and 1991 and the worst conventionally measured recession in decades, which pushed the unemployment rate over the 11 per cent mark.

The recent pattern of the wealth cycle weighs against the proposition that Australia's macroeconomic policy-makers have the wherewithal to manage overall activity smoothly and costlessly. To the extent that the wealth cycle can be partly explained by the overuse of macroeconomic policy, this strengthens the case for placing more emphasis on rules to limit the discretionary powers presently exercised by the fiscal and monetary authorities. Rule-based alteniatives, for instance, would include the adoption of a target for money-base growth as well as explicit limits on the extent to which discretionary spending and tax rates could change from year to year, in order to minimise fiscal uncertainty. Of course, this is not to suggest that less interventionist macroeconomic policy would entirely eliminate the real wealth and real GDP cycles. Even with less manipulative fiscal and monetary policy, the economy would still be subject to a range of other domestic and foreign influences.

\section{References}

Australian Bureau of Statistics (ABS) (1995), Nationa/ Balance Sheets in Australia: Issues and Experimer tal Estimates, Canberra (Cat. No. 5241.0).

Fama, E. (1976), Fourdations or Finance, Basic Books, New York.

Keynes, J. (1936), The General Theory of Employment, Interest and Money, Macmillan, London.

Makin, A. (1994), National Wealth Statements: New Estimates and Uses, University of Queensland, Brisbane (Department of Economics Discussion Paper No. 154).

Malkiel, B. (1989), 'Efficient Markets Hypothesis', in J. Eatwell, M. Milgate, \& P. Newman (eds), The New Palgrave: Finance, Macmillan, London.

Tony Makin is Senior Lecturer in Economics at the University of Queensland. 